\title{
KEPEMIMPINAN KYAI DALAM MENGAKTUALISASIKAN MODERNISASI PENDIDIKAN PESANTREN DI PERGURUAN TINGGI (STUDI INTERAKSIONISME SIMBOLIK DI MA'HAD SUNAN AMPEL AL-'ALY UIN MALIKI MALANG)
}

\section{Devi Pramitha}

Fakultas Ilmu Tarbiyah dan Keguruan Universitas Islam Negeri Maulana Malik Ibrahim Malang e-mail: phe2_90@yahoo.co.id

\begin{abstract}
The Kiai as the leader of the boarding school is not just to lead, but also develop curricula, create evaluation system, determine the order of the institution came to organize the life of the whole community of cottage boarding and also foster community. In this study, there are three objectives are achieved, namely: (1) obtain a description and a complete picture of the behavior of the leadership of clerics; (2) obtain a description and a complete picture of the interaction patterns clerics; and (3) obtaining a description and a complete overview of the concept of modernization of education schools in Higher Education

This type of research is qualitative and using the case study method. Ma'had Sunan Ampel Al-'Aly selected as the research object because it is the first boarding school students in the environment PTAIN. Data obtained by interview (interview), documents (documents) and observations (observation). Spradley data analysis using a model consisting of domain analysis, analasis taxonomy, componential analysis and thematic analysis.

Three results obtained, namely, (1) Conduct Yai Chamzawi leadership in MSAA UIN Maliki leads to transformational leadership; (2) The pattern of interaction Yai Chamzawi in MSAA UIN Maliki leads to the traditional leadership; and (3) The concept of modernization of education schools in universities based on the principle of al-Muhafadzatu 'ala qadimi as-salih wa al-akhdu bi aljadidi al-aslah. So from the third conclusion above can researchers find a style of leadership clerics in MSAA UIN Maliki is Leadership Style Neo-Transformasionalisme, which is a combination of leadership styles transfomasionalisme and leadership style traditionalism based on the principle of al-muhafadzatu 'alal qadimi shalih wal akhdu bil jadidil ashlah.
\end{abstract}

Keywords: Leadership of Kyai, Modernization of Islamic Boarding Scool Education, College 
Devi Pramitha - Kepemimpinan Kyai dalam Mengaktualisasikan Modernisasi Pendidikan Pesantren di Perguruan Tinggi (Studi Interaksionisme Simbolik Di Ma'had Sunan Ampel al-'Aly Uin Maliki Malang)

\begin{abstract}
Abstrak: Kiai sebagai pemimpin pondok pesantren tidak hanya sekedar memimpin, tetapi juga menyusun kurikulum, membuat sistem evaluasi, menentukan tata tertib lembaga sampai pada menata kehidupan seluruh komunitas pondok pesantren dan juga membina masyarakat. Penelitian ini ada tiga tujuan yang dicapai, yaitu: (1) memperoleh deskripsi dan gambaran lengkap tentang perilaku kepemimpinan kyai; (2) memperoleh deskripsi dan gambaran lengkap tentang pola interaksi kyai; dan (3) memperoleh deskripsi dan gambaran lengkap tentang konsep modernisasi pendidikan pesantren di Perguruan Tinggi

Jenis penelitian ini adalah kualitatif dan menggunakan metode studi kasus. Ma'had Sunan Ampel Al-`Aly dipilih sebagai objek penelitian karena merupakan pesantren mahasiswa pertama yang ada di lingkungan PTAIN. Data diperoleh dengan wawancara (interview), dokumen-dokumen (documents) dan observasi (observation). Analisis data menggunakan model Spradley yang terdiri dari analisis domain, analasis taksonomi, analisis komponensial dan analisis tema.

Hasil temuan yang diperoleh, yaitu, (1) Perilaku kepemimpinan Yai Chamzawi di MSAA UIN Maliki Malang mengarah kepada kepemimpinan transformasional; (2) Pola interaksi Kiai Chamzawi di MSAA UIN Maliki Malang mengarah kepada kepemimpinan tradisional; dan (3) Konsep modernisasi pendidikan pesantren di Perguruan Tinggi berdasarkan prinsip alMuhafadzatu 'ala qadimi as-salih wa al-akhdu bi al-jadidi al-aslah. Sehingga dari ketiga kesimpulan diatas peneliti dapat menemukan gaya kepemimpinan kyai di MSAA UIN Maliki Malang adalah Gaya Kepemimpinan Neo-Transformasionalisme, yang merupakan gabungan dari gaya kepemimpinan transfomasionalisme dan gaya kepemimpinan tradisionalisme yang dilandasi dengan prinsip almuhafadzatu 'alal qadimi shalih wal akhdu bil jadidil ashlah.
\end{abstract}

Kata Kunci: Kepemimpinan Kyai, Modernisasi Pendidikan Pesantren, Perguruan Tinggi

\title{
Pendahuluan
}

Pesantren merupakan sebuah lembaga pendidikan tertua yang melekat dalam perjalanan kehidupan Indonesia sejak ratusan tahun yang silam, ia adalah lembaga pendidikan yang dapat dikategorikan sebagai lembaga unik dan punya karakteristik tersendiri yang khas, sehingga saat ini menunjukkan kapabilitasnya yang cemerlang melewati berbagai episode zaman dengan pluralitas polemik yang 
Devi Pramitha - Kepemimpinan Kyai dalam Mengaktualisasikan Modernisasi Pendidikan Pesantren di Perguruan Tinggi (Studi Interaksionisme Simbolik Di Ma'had Sunan Ampel al-'Aly Uin Maliki Malang)

dihadapinya. Pesantren juga melayani kebutuhan (needs) pendidikan ketika masyarakat memerlukannya, terutama ketika lembaga-lembaga pendidikan modern yang pada umumnya bersifat formal, belum mampu menembus ke pelosok desa. Pada saat itu dunia pesantren menjadi simbol yang menghubungkan dunia pedesaan dengan dunia luar (In'am, 2000: 3).

Secara historis, pesantren merupakan lembaga pendidikan Islam yang dikembangkan secara indigenous oleh masyarakat Indonesia. Karena sebenarnya pesantren merupakan produk budaya masyarakat Indonesia yang sadar sepenuhnya akan pentingnya arti sebuah pendidikan bagi orang pribumi yang tumbuh secara natural. Nurcholis Madjid mengatakan bahwa dari segi historis, pesantren tidak hanya identik dengan makna keIslaman, tetapi juga mengandung makna keaslian Indonesia (indigenous) (Madjid, 1997: 59). Pesantren juga dianggap sebagai satu-satunya sistem pendidikan di Indonesia yang menganut sistem tradisional (konservatif). Sebagaimana dikatakan Ulil Abshar Abdalah bahwa pesantren merupakan satusatunya lembaga pendidikan Islam di Indonesia yang mewarisi tradisi intelektual tradisional (Ulil, 1999: 287).

Yang menarik di sini adalah bahwa pendidikan pesantren di Indonesia pada saat itu sama sekali belum terstandarisasi secara kurikulum dan tidak terorganisir sebagai satu jaringan manajemen pesantren Indonesia yang sistemik. Ini berarti bahwa setiap pesantren mempunyai kemandirian sendiri untuk menerapkan system kurikulum dan mata pelajaran yang sesuai dengan aliran agama Islam yang mereka ikuti. Sehingga, ada pesantren yang menerapkan kurikulum Kemendiknas (Kementerian Pendidikan Nasional) dengan menerapkan juga kurikulum agama. Kemudian, ada pesantren yang hanya ingin memfokuskan pada kurikulum ilmu agama Islam saja. Yang berarti bahwa tingkat keanekaragaman model pesantren di Indonesia tidak terbatasi pada konteks dependensi kekhususan disiplin ilmu, akan tetapi plural dalam bentuk independensinya (Umiarso \& Zazin, 2011: 4).

Begitu juga dengan pola pendidikan dan pengajaran di pondok pesantren yang masih erat kaitannya dengan tipologi pondok pesantren maupun ciri-ciri (karakteristik) pondok pesantren itu sendiri. Dalam melaksanakan proses pendidikan sebagian besar pesantren di Indonesia pada umumnya menggunakan beberapa sistem pendidikan dan pengajaran yang bersifat tradisional. Sistem tradisional adalah sistem yang berangkat dari pola pengajaran yang sangat sederhana, yakni pola pengajaran sorogan, bandongan, wetonan, dan 
musyawarah dalam mengkaji kitab-kitab agama yang ditulis oleh para ulama zaman abad pertengahan yang mana kitab-kitab itu dikenal dengan istilah kitab kuning (Binti, 2009: 29). Beberapa pola pengajaran tersebut sebenarnya tergantung pada Kyai sebagai pemimpin dan pengelola pondok pesantren, sebab segala sesuatu yang berhubungan dengan materi pembelajaran, sistem pengajaran, sampai waktu dan tempat pembelajaran disesuaikan dengan keinginan sang Kyai. Karena bagaimanapun juga Kyai di sini sangat dominan di dalam pelaksanaan pendidikan di pondok pesantren, selain karena dia sendiri merupakan simbol kepemimpinan di pondok pesantren.

Di dalam perkembangannya, pondok pesantren tidaklah semata-mata kemudian tumbuh secara stagnan dalam artian selalu berada atas pola lama yang bersifat tradisional, melainkan bisa dilakukan suatu inovasi dalam pengembangan sistem pendidikan di pondok pesantren tersebut. Modernisasi yang dalam bentuk umum Indonesia lebih dikenal dengan istilah "pembangunan" (development) adalah proses multi dimensional yang komplek. Modernisasi paling awal dari sistem pendidikan di Indonesia harus diakui tidak bersumber dari kalangan kaum muslim sendiri. Kemunculan modernisasi pendidikan Islam di Indonesia berkaitan erat dengan pertumbuhan gagasan modernisme Islam di kawasan ini. Dalam lapangan pendidikan, modernisasi setidaknya dapat dilihat dengan direalisasikannya pembentukan lembaga-lembaga pendidikan modern yang mengadopsi dari sistem dan kelembagaan kolonial Belanda, bukan dari sistem pendidikan Islam tradisional.

Pada awal perkembangan gagasan modernisme pendidikan Islam terdapat dua kecenderungan pokok yang mendasari upaya ke arah modernisasi organisasi-organisasi Islam. Di satu pihak adopsi sistem dan lembaga pendidikan modern secara hampir menyeluruh. Titik tolak modernisme pendidikan Islam di sini adalah sistem kelembagaan pendidikan modern (Belanda), bukan sistem dan lembaga pendidikan Islam tradisonal. Pada pihak lain terdapat upaya yang bertitik tolak justru dari sistem dan kelembagaan pendidikan Islam itu sendiri. Di sini lembaga pendidikan Islam yang sebenarnya telah ada sejak waktu lama dimodernisasi. Sistem pendidikan pesantren dan surau yang merupakan lembaga pendidikan Islam asli (pribumi) dimodernisasi, misalnya dengan mengambil atau mencontoh aspek-aspek tertentu dari sistem pendidikan modern, khususnya dalam kandungan kurikulum, teknik dan metode pengajaran, dan sebagainya (Azra, 1999: 90).

Perguruan tinggi dan pesantren adalah dua tradisi pendidikan 
yang mempunyai banyak perbedaan. Perguruan tinggi merupakan gejala di perkotaan, sedangkan pesantren merupakan gejala di pedesaan; perguruan tinggi identik dengan kemodernan, pesantren identik dengan ketradisionalan; perguruan tinggi lebih menekankan pendidikan yang bersifat liberal, pesantren lebih menekankan sikap konservatif yang bersandar karena berpusat pada figur sang kiai; dan seterusnya. Persepsi dualisme dikotomik semacam itu mungkin saja kurang begitu tepat, karena pada kenyataannya banyak juga pesantren yang telah melakukan perubahan baik secara struktural maupun kultural. Munculnya banyak pesantren dengan klaim pesantren modern, yang bisa saja terkesan supervisial bagaimanapun telah menjadi petunjuk penting hahwa pesantren tidak selamanya memperlihatkan perkembangan yang statis atau status quo. Maka kalau perguruan tinggi sering diberi citra "wah", tidak berarti keberadaannya lebih unggul dibandingkan pesantren. Bahkan, kalau dilihat dari sisi kemandirian, pesantren mempunyai kelebihan. Dan kalau mau jujur, sebenarnya lembaga yang paling bertanggung jawab terhadap munculnya fenomena masyarakat pendidikan berlebih (overeducated society) yang dapat dilihat pada semakin membludaknya pengangguran intelektual di kota sekarang ini, adalah perguruan tinggi itu.

Belakangan kita menyaksikan terjadinya sintesa atau konvergensi antara pesantren dengan perguruan tinggi, hal itu dapat dipandang sebagai perkembangan yang konstruktif. Seperti kita ketahui, banyak pesantren yang mendirikan perguruan tinggi, dan sebaliknya. Atau di beberapa kota mulai didirikan pesantren yang bernuansakan dunia perguruan tinggi, meskipun di dalamnya tidak ada pendidikan yang secara formal disebut perguruan tinggi. Dalam pandangan Islam, mahasiswa merupakan komunitas yang terhormat dan terpuji (QS.al-Mujadalah :11), karena ia merupakan komunitas yang menjadi cikal bakal lahirnya ilmuan (ulama') yang diharapkan mampu mengembangkan ilmu pengetahuan dan memberikan penjelasan pada masyarakat dengan pengetahuannya itu (QS alTaubah:122). Oleh karenanya, mahasiswa dianggap sebagai komunitas yang penting untuk menggerakkan masyarakat Islam menuju kekhalifahannya yang mampu membaca alam nyata sebagai sebuah keniscayaan ilahiyah (QS.Ali-Imran:191).

Universitas Islam Negeri Maulana Malik Ibrahim Malang adalah salah satu perguruan tinggi yang memandang keberhasilan pendidikan mahasiswa apabila mereka memiliki identitas sebagai seseorang yang mempunyai: (1) ilmu pengetahuan luas, (2) penglihatan yang tajam, 
Devi Pramitha - Kepemimpinan Kyai dalam Mengaktualisasikan Modernisasi Pendidikan Pesantren di Perguruan Tinggi (Studi Interaksionisme Simbolik Di Ma'had Sunan Ampel al-'Aly Uin Maliki Malang)

(3) otak yang cerdas, (4) hati yang lembut dan (5) semangat tinggi karena Allah (Tarbiyatu Uli al-Albab: Dzikir, Fikir dan Amal Sholeh, 2005:5).

Untuk mencapai keberhasilan tersebut, kegiatan kependidikan di Universitas Islam Negeri (UIN) Maliki Malang, baik kurikuler, kokurikuler maupun ekstra kurikuler, diarahkan pada pemberdayaan potensi dan kegemaran mahasiswa untuk mencapai target profil lulusan yang meiliki cirri-ciri: (1) kemandirian, (2) siap berkompetisi dengan lulusan Perguruan Tinggi lain, (3) berwawasan akademik global, (4) kemampuan memimpin/sebagai penggerak umat, (5) bertanggung jawab dalam mengembangkan agama Islam di tengahtengah masyarakat, (6) berjiwa besar, dan (7) kemampuan menjadi tauladan bagi masyarakat sekelilingnya (Visi, Misi dan Tradisi UIN Maliki Malang, 2006:5).

Strategi tersebut mencakup pengembangan kelembagaan dan tercermin dalam: (1) kemampuan tenaga akademik yang handal dalam pemikiran, penelitian, dan berbagai aktivitas ilmiah-religius, (2) kemampuan tradisi akademik yang mendorong lahirnya kewibawaan akademik bagi seluruh civitas akademika, (3) kemampuan manajemen yang kokoh dan mampu menggerakkan seluruh potensi untuk mengembangkan kreatifitas warga kampus, (4) kemampuan antisipatif masa depan dan bersifat proaktif, (5) kemampuan pimpinan mengakomodasikan seluruh potensi yang dimiliki menjadi kekuatan penggerak lembaga secara menyeluruh, dan (6) kemampuan membangun biah Islamiyah yang mampu menumbuhsuburkan akhlakul karimah bagi setiap civitas akademika.

Untuk mewujudkan harapan terakhir, salah satunya adalah dibutuhkan keberadaan ma'had yang cera intensif mampu memberikan resonansi dalam mewujudkan lembaga pendidikan tinggi Islam yang ilmiah-religius, sekaligus sebagai bentuk penguatan terhadap pembentukan lulusan yang intelek-profesional. Hal ini benar karena tidak sedikit keberadaan ma'had telah mampu memberikan sumbangan besar bagi bangsa ini melalui alumninya dalam mengisi pembangunan manusia seutuhnya. Dengan demikian, keberadaan ma'had dalam komunitas perguruan tinggi Islam merupakan keniscayaan yang akan menjadi pilar penting dari banyunan akademik.

Saat ini, dilihat dari keberadannya, asrama mahasiswa di Indonesia dapat diklasifikasikan menjadi tiga model. Pertama, asrama mahasiswa sebagai tempat tinggal sebagian mahasiswa aktif dan berprestasi dengan indikasi nilai Indeks Prestasi (IP) tinggi. Kegiatan yang ada di asrama model ini ialah kegiatan yang diprogramkan oleh 
Devi Pramitha - Kepemimpinan Kyai dalam Mengaktualisasikan Modernisasi Pendidikan Pesantren di Perguruan Tinggi (Studi Interaksionisme Simbolik Di Ma'had Sunan Ampel al-'Aly Uin Maliki Malang)

para penghuninya, sehingga melahirkan kesan terpisah dari cita-cita perguran tinggi. Kedua, asrama mahasiswa sebagai tempat tinggal pengurus atau aktivis intra dan ekstra kampus. Kegiatan yang ada di asrama model kedua ini banyak terkait dengan kegiatan rutinitas intra dan ekstra kampus tanpa ada control dari perguruan tinggi. Ketiga, asrama mahsiswa sebagai tempat tinggal sebagian mahasiswa yang memang berkeinginan berdomisili di asrama kampus, tanpa ada persyaratan tertentu. Oleh sebab itu kegiatan yang ada di asrma model ketiga inipun tidak terprogram secara baik dan terkadang kurang mendukung terhadap visi dan misi perguruan tinggi-nya.

Berdasarkan dari filosofi ini dan misi diatas, sekaligus dari hasil pembacaan terhadap model asrama mahasiswa yang ada selama ini, Universitas Islam Negeri (UIN) Maliki Malang memandang bahwa pendirian ma'had dirasa sangat urgen bagi upaya merealisasikan semua program kerjanya secara integral dan sistematis, sejalan dan sinergis dengan visi dan misi UIN Maliki Malang.

Sekalipun pondok pesamtren tersebut berada di lingkungan perguruan tinggi namun tetap saja di dalam pondok pesantren terdapat beberapa unsur yang dalam hal-hal tertentu dapat membedakan dengan sistem pendidikan lainnya. Salah satu unsur yang sangat mencolok dalam perbedaannya tersebut adalah adanya sosok Kyai. Kyai sebagai pemimpin tertinggi di pesantren memiliki kewibawaan yang hampir mutlak. Di lingkungan ini tidak ada orang lain yang lebih dihormati daripada Kyai (Pradjarta, 1999: 156). Sehingga seorang Kyai yang menjadi pengasuh (pimpinan tertinggi) di pondok pesantren memiliki kebebasan yang tak terbatas untuk mengambil segala tindakan dan kebijakan yang terkait dengan pendidikan di pondok pesantren tersebut. Apapun upaya perubahan maupun pembaharuan yang akan dilakukan oleh pihak pesantren, tentu tidak akan berhasil selama tidak mendapat dukungan dari Kyainya.

Realitas ini memungkinkan Kyai berkontribusi besar terhadap aneka problem keumatan. Peran Kyai tidak hanya terbatas pada aspek spiritual, namun juga aspek kehidupan sosial yang lebih luas (Wahid, 1987: 200). Di tengah-tengah krisis kepemimpinan saat ini, baik dalam sistem pemerintahan maupun kenegaraan Indonesia yang bisa dinilai tidak memiliki moralitas cukup, pengembalian peran tokoh bermoral seperti Kyai menjadi sebuah jawaban agar Kyai tidak hanya bisa menjadi penjaga moralitas umat, tetapi juga mengembalikan tata perpolitikan dan pendidikan Indonesia yang mengedepankan karakter bangsa Indonesia serta moralitas. Keberadaan Kyai yang merupakan 
pengasuh sekaligus pimpinan pondok pesantren, ditinjau dari peran dan fungsinya dapat dipandang sebagai suatu fenomena kepemimpinan yang unik. Mengapa demikian, karena selain memimpin lembaga pendidikan Islam yang tidak hanya bertugas menyusun kurikulum, membuat tata tertib, merancang sistem evaluasi sekaligus melaksanakan proses belajar mengajar yang berkaitan dengan ilmu agama yang diasuhnya, dia juga berperan sebagai pembina, pendidik umat serta pemimpin masyarakat.

Di dalam proses kepemimpinannya pastinya akan muncul sebuah interaksi (hubungan) Kyai dengan komunitasnya di pondok pesantren. Dalam kehidupan sehari-hari, Kyai dapat memberikan motivasi spiritual kepada para komunitasnya untuk dapat meningkatkan produktivitas kinerja dalam rangka mencapai tujuan organisasi pondok pesantren. Misalnya, melalui taushiyah (pesan normatif) jika seseorang banyak berbuat kebaikan maka ia kelak akan mendapatkan balasan pahala dan rahmat dari Allah SWT, atau dengan menggunakan pendekatan motivasi penteladanan (uswah), seorang Kyai senantiasa shalat lima waktu dengan berjamaah secara istiqamah (continual). Selain itu seorang Kyai sebagai pemimpin pondok pesantren juga harus mampu berinteraksi positif dengan komunitasnya, mengkomunikasikan ide-ide dan rumusan visi-misi lembaga yang dipimpinnya. Peran ini didasari pada keyakinan bahwa sebuah interaksi di pondok pesantren merupakan sarana penting untuk mencapai visi-misi, dan tujuan organisasi pondok pesantren.

Adanya fenomena maupun studi sosial tentang pemimpinpemimpin Islam di Indonesia menunjukkan bahwa Kyai merupakan tokoh yang mempunyai posisi sentral dan strategis di lingkungan masyarakat. Oleh sebab itu, keberadaan Kyai sebagai pemimpin pondok pesantren sangatlah vital, karena keberhasilan pondok pesantren sebagian besar terletak pada faktor kepemimpinan Kyai. Kepemimpinan Kyai di pondok pesantren seperti yang dikatakan oleh sebagian pakar bahwa hampir semua kepemimpinan di pondok pesantren itu bersifat individual yang sangat tergantung dengan kharisma Kyai yang memimpin di pondok pesantren tersebut. Akan tetapi, walaupun demikian tidak bisa dikatakan begitu saja sebagai kepemimpinan yang otoriter, karena kepemimpinan Kyai telah terbentuk sedemikian rupa sesuai dengan nilai-nilai kepemimpinan yang dicontohkan oleh Rasulullah. Sehingga jika dilihat dari pola kepemimpinan yang religio paternalistik, pola interaksi antara Kyai dengan anggota komunitasnya cenderung bersifat kekeluargaan. Dengan menggunakan pola kepemimpinan religio paternalistik ini, Kyai 
Devi Pramitha - Kepemimpinan Kyai dalam Mengaktualisasikan Modernisasi Pendidikan Pesantren di Perguruan Tinggi (Studi Interaksionisme Simbolik Di Ma'had Sunan Ampel al-'Aly Uin Maliki Malang)

dalam berinteraksi dengan komunitasnya menjadi erat tanpa menyampingkan etika interaksi sebagaimana seharusnya.

Dalam kajan sosiologi, ada fenomena kehidupan sosial yang diparalelkan dengan teori interaksionisme simbolik. Interaksionisme simbolik adalah teori yang mempelajari sifat interaksi dimana hal tersebut merupakan kegiatan sosial dinamis manusia. George Herbert Mead dan Herbert Blumer adalah tokoh yang mengembangkan teori ini. Dalam perspektif ini setidaknya ada beberapa premis yang dipahami, yaitu; makna simbol, diri (self), interaksi sosial, dan masyarakat. Dalam perspektif ini, individu bersifat aktif, reflektif, dan kreatif, menafsirkan, menampilkan perilaku yang rumit dan sulit diramalkan. Teori ini menolak gagasan bahwa individu adalah organisme yang pasif yang perilakunya ditentukan oleh kekuatankekuatan atau struktur yang ada diluar dirinya. Oleh karena individu terus berubah maka masyarakat pun berubah melalui interaksi. Jadi, pada intinya, bukan struktur masyarakat melainkan interaksi lah yang dianggap sebagai variabel penting dalam menentukan perilaku manusia. Melalui percakapan dengan orang lain, kita lebih dapat memahami diri kita sendiri dan juga pengertian yang lebih baik akan pesan-pesan yang kita dan orang lain kirim dan terima (Richard \& Lynn, 2008: 93).

Teori Blumer di atas jika digunakan untuk menganalisis kepemimpinan Kyai di pondok pesantren menarik untuk dikaji, tentang simbol misalnya, kepemimpinan Kyai di pondok pesantren dalam mengaktualisasikan konsep pemikirannya terkadang hanya menggunakan simbol-simbol tertentu yang jika dijelaskan dapat menguak tabir apa arti sebenarnya dari simbol-simbol tersebut. Fenomena sosial lainnya adalah fenomena kehidupan yang dipararelkan dengan panggung sandiwara atau teater. Erving Goffman, seorang sosiolog Amerika, mengasumsikan kehidupan dunia sosial dengan panggung sandiwara atau teater. Ia mengemukakan bahwa, kehidupan sosial terdiri dari penampilan teatrikal yang diritualkan, yang kemudian lebih terkenal dengan pendekatan Dramaturgi (Dramaturgical Approuach). Artinya bahwa dalam kehidupan sosial, seseorang sesungguhnya tengah menampilkan rentetan peran. Tampilan dari rentetan peran ini 'harus' ia mainkan secara baik dan tepat, karena orang di luarnya menghendaki demikian. Orang di luarnya, penonton dalam bahasa teater atau drama, menghendaki ia tampil sesempurna mungkin. Mereka seringkali tidak mempedulikan berbagai macam kendala yang dihadapi 'si aktor' ketika ia tidak hanya sedang memainkan satu peran, tetapi serentetan peran. Memang 
Devi Pramitha - Kepemimpinan Kyai dalam Mengaktualisasikan Modernisasi Pendidikan Pesantren di Perguruan Tinggi (Studi Interaksionisme Simbolik Di Ma'had Sunan Ampel al-'Aly Uin Maliki Malang)

seperti itulah penonton, menginginkan suatu pertunjukan sesuai dengan kehendaknya.

Teori di atas, apabila dikaitkan dengan kepemimpinan Kyai terhadap konsep pemikirannya, maka boleh jadi ada beberapa kemungkinan ketika mengungkap apa sesungguhnya yang dilakukan oleh Kyai yang berperan sebagai pemimpin di pondok pesantren dalam mengaktualisasikan konsep pemikirannya kepada para komunitas pondok pesantren (santri, pengurus, ustadz). Bisa jadi para komunitas pondok pesantren melaksanakan tugas-tugasnya dengan dasar pengabdian dan mendedikasikan diri mereka atas dasar komitmen dan ketulusan, atau mungkin mereka melaksanakan program-program pondok pesantren bukan atas dasar kesetiaan, dan ketulusan saja, akan tetapi karena mereka ada ketergantungan kepada Kyai yang diikuti (istinâd), baik ketergantungan terhadap status sosial ekonomi, atau bahkan mereka melakukan semua aktivitas-aktivitas atas dasar sebagaimana yang diungkapkan Weber, bahwa mereka tersebut melakukan tindakan-tindakan rasionalitas nilai (Wertrational). Rasionalitas nilai adalah tindakan yang dipengaruhi oleh keyakinan dan ketertarikan terhadap suatu tatanan nilai yang tinggi seperti kebenaran, keindahan, keadilan, atau kepercayaan kepada Tuhan. Dengan demikian keyakinan yang demikian dapat menyebabkan timbulnya "kesetiaan", "ketaatan", dan "kepatuhan" komunitas pondok pesantren.

Berdasarkan hal-hal sebagaimana diuraikan di atas, maka penelitian ini memfokuskan pada kajian tentang "Kepemimpinan Kyai dalam Mengaktualisasikan Modernisasi Pendidikan Pesantren di Perguruan Tinggi (Studi Interaksionisme Simbolik di Ma'had Sunan Ampel Al-'Aly UIN Maulana Malik Ibrahim Malang)".

\section{METODE PENELITIAN}

Penelitian tentang kepemimpinan Kyai dalam mengaktualisasikan modernisasi pendidikan pesantren di perguruan tinggi (studi interaksionisme simbolik di Ma'had Sunan Ampel Al-'Aly UIN Maulana Malik Ibrahim Malang) ini merupakan suatu penelitian yang dapat dikategorikan sebagai penelitian kualitatif. Dalam implementasinya, penelitian ini dilakukan dengan menggunakan pendekatan fenomenologi. Selain itu, dalam penelitian yang menggunakan pendekatan fenomenologi ini, peneliti juga melibatkan perspektifnya pada interaksi simbolik. Interaksi (interaksionisme) simbolik merupakan salah satu di antara beberapa perspektif utama yang dikenal dalam ilmu-ilmu sosial, seperti sosiologi, psikologi, 
antropologi, dan komunikasi. Namun, belakangan bidang-bidang lain seperti pendidikan, politik, dan bidang kemasyarakatan lainnya mulai menggunakan perspektif ini dalam mengkaji topik-topik kajiannya. Sehingga dalam hal ini, peneliti berusaha untuk memahami subjek penelitiannya dari sudut pandang subjek itu sendiri dengan tidak mengabaikan dalam membuat penafsiran dan membuat skema konseptual (Ulfiatin, 2013: 96).

Dalam melaksanakan penelitian ini, sebelum melakukan wawancara, peneliti menentukan orang-orang yang peneliti tentukan sebagai informan, meliputi: Drs. KH. Chamzawi, M.HI, sebagai informan kunci dalam penelitian ini, beliau adalah dewan pengasuh MSAA. Selanjutnya, peneliti mengambil informan dari pihak Mudir, sekertaris Ma'had dan beberapa ketua bidang. Dalam penelitian ini, peneliti menggunakan model analisis data yang digagas oleh Moustakas, yang terdiri dari beberapa tahapan, yaitu: collecting data, horizontalizing of data based on topic, clustering theme, textural and structural description, and finding meaning and essence.

\section{HASIL PENELITIAN}

\section{Perilaku Kepemimpinan Kyai dalam Mengaktualisasikan Modernisasi Pendidikan Pesantren di Ma'had Sunan Ampel Al-'Aly UIN Maulana Malik Ibrahim Malang}

Sebagaimana kita ketahui bersama bahwa proses transformasi sosio-kultural yang berlangsung dewasa ini hampir menjamah setiap sudut kehidupan masyarakat. Pondok pesantren yang sering disebutsebut sebagai lembaga pendidikan tertua yang menjaga nilai-nilai tradisionalnya pun tidak lepas dari jangkauan proses tersebut. Meski demikian pondok pesantren mampu mempertahankan eksistensinya sebagai filter budaya asing sehingga tetap survive di jaman modern ini. Keberhasilan pondok pesantren dalam perjalanan transformasi sosio kultural yang dilaluinya ini tidak lepas dari peran kepemimpinan Kyai di dalamnya. Terlebih dewasa ini Perguruan Tinggi juga tidak mau kalah untuk memasukan system pendidikan pesantren didalamnya.

Adanya sosok Kyai sebagai pemimpin pondok pesantren menjadi salah satu faktor yang sangat menentukan akan kesuksesan pondok pesantren. Dalam penelitian ini ditemukan beberapa perilaku yang telah dilakukan oleh Yai Chamzawi dalam memimpin MSAA. Pertama, Yai Chamzawi mampu menjadikan dirinya sebagai sosok pemimpin yang ideal di mata para bawahan melalui kharisma yang dimilikinya. Kharisma tersebut terlihat dari segi keilmuan yang dimiliki oleh Yai Chamzawi, baik ilmu natural maupun supranatural. Selain itu 
Devi Pramitha - Kepemimpinan Kyai dalam Mengaktualisasikan Modernisasi Pendidikan Pesantren di Perguruan Tinggi (Studi Interaksionisme Simbolik Di Ma'had Sunan Ampel al-'Aly Uin Maliki Malang)

sebagai seorang pemimpin Yai Chamzawi memiliki ide besar, yakni melakukan modernisasi pendidikan pesantren di Perguruan Tinggi, yang didorong oleh keyakinan dan niat kuat dalam mewujudkanya, serta komitmen dan konsisten dalam proses pelaksanaannya.

Kedua, sebagai seorang pimpinan MSAA, Yai Chamzawi piawai dalam memotivasi dan menginspirasi anggota bawahannya untuk memiliki semangat yang tinggi dalam mengembangkan pondok pesantren. Beberapa strategi yang dilakukan oleh Yai Chamzawi, antara lain: (1) menjadikan dirinya sebagai uswatun hasanah/teladan yang baik bagi para bawahannya; (2) memberikan reward/ penghargaan bagi anggota bawahannya yang melakukan pekerjaan dengan baik; (3) selalu mengadakan muhasabah bersama setiap bulan dalam rangka menuju perubahan dan perbaikan serta menjadi salah satu media komunikasi Yai Chamzawi dengan semua anggota bawahannya.

Ketiga, walaupun Yai Chamzawi merupakan pengasuh dan pimpinan MSAA, namun tidak menjadikan dirinya sebagai seorang pemimpin tunggal yang otoriter terhadap bawahannya. Karena menginginkan suasana organisasi yang demokratis, Yai Chamzawi pun memberikan kewenangan yang ada pada dirinya kepada semua anggota bawahan melalui cara pendelegasian tugas-tugas. Hal tersebut dilakukan sebagai sebuah stimulus bagi bawahannya untuk dapat mengembangkan potensi yang dimilikinya secara bebas dalam rangka mencapai visi dan misi pondok pesantren.

Keempat, sebagai seorang pemimpin dan juga seorang Kyai, Yai Chamzawi mampu memberikan perhatiannya terhadap bawahannya baik secara individu maupun bersama-sama. Secara individu dilakukan oleh Yai Chamzawi melalui diskusi empat mata dan bertukar pikiran baik menyangkut persoalan MSAA maupun persoalan pribadi. Sedangkan untuk memberi perhatian kepada semua anggota bawahannya Yai Chamzawi selalu mengadakan pertemuan di kediamannya setiap akhir bulan dan mengadakan acara yang melibatkan mereka.

Dengan perilaku kepemimpinan kiai di tempat penelitian ini, maka peneliti mengidentifikasi bahwa perilaku kepemimpinan Yai Chamzawi di MSAA adalah kepemimpinan transformasional. Sebagaimana dijelaskan dalam bab II, kepemimpinan transformasional menunjuk pada proses membangun komitmen terhadap sasaran organisasi dan memberi kepercayaan kepada para pengikut untuk mencapai sasaran-sasaran tersebut. Sehingga pemimpin transformasional berupaya untuk melakukan transforming of visionary 
menjadi visi bersama (pemimpin dan bawahan). Dengan kata lain, Menurut Yukl, kepemimpinan transformasional terlihat melalui sejumlah perilaku kepemimpinan seperti: idealized influence, inspirational motivation, intellectual stimulation dan individualized consideration (Yukl, 2000: 287).

Review yang dilakukan Coulson dalam Saran \& Trafford menyebutkan bahwa pemimpin pendidikan yang transformasional ditandai dengan kemampuan pemimpin menjawab berbagai tantangan, memelihara visi tentang sekolah yang baik dan upaya mencapainya dengan energi dan komitmen yang tinggi, serta menunjukkan kualitas personal yang mengacu pada integritas moral (Coulson, 1990: 101 107). Sementara menurut Burns, kepemimpinan transformasional merupakan sebuah proses di mana para pemimpin dang pengikut saling menaikkan diri ke tingkat moralitas dan motivasi yang lebih tinggi. dalam hubungannya dengan tingkat kebutuhan Maslow, pemimpin transformasional perlu meningkatkan kebutuhan bawahan dari tingkat yang paling dasar ke tingkatan puncak yakni aktualisasi diri.

Sehingga dengan perilaku kepemimpinan Yai Chamzawi yang mengarah kepada kepemimpinan transformasional, dapat menumbuhkan semangat pada anggota bawahannya untuk tercapainya visi dan misi UIN Maliki Malang. Karena dalam kepemimpinan transformasional orientasinya adalah meningkatkan komitmen bawahan terhadap pencapaian tujuan.

Maka dari pembahasan dan uraian di atas terkait dengan perilaku kepemimpinan kiai, dapat dirumuskan proposisi sebagai berikut:

Memiliki kharisma, menjadi motivator dan sosok yang inspiratif, menciptakan suasana organisasi yang demokratis dengan pendelegasian tugas, serta peduli terhadap bawahannya merupakan perilaku kepemimpinan Yai Chamzawi di MSAA yang mengarah kepada gaya kepemimpinan transformasional.

\section{Pola Interaksi Kyai dalam Mengaktualisasikan Modernisasi Pendidikan Pesantren di Ma'had Sunan Ampel Al-'Aly UIN Maulana Malik Ibrahim Malang}

Dalam memimpin MSAA, Yai Chamzawi senantiasa berusaha untuk menyeimbangkan interaksi antara kiai dengan komunitas pondok pesantrennya, baik komunitas internal (mahasantri dan dosen/ asatidz) maupun komunitas eksternal (masyarakat), melalui 
interaksi fisik, interaksi pola pikir, dan interaksi ruh/ batin. Dengan demikian baik para mahasantri, dosen/ asatidz, staff maupun masyarakat bisa ikut berperan serta dalam mengembangkan ma'had al-jami'ah sebagai pelaku perubahan (agent of change) dalam berbagai aspek kehidupan. Dari berbagai paparan data sebelumnya terlihat pola interaksi Yai Chamzawi dengan mahasantri, dosen/ asatidz dan juga masyarakat.

Pertama, dalam berinteraksi dengan para mahasantri, Yai Chamzawi menjadikan dirinya tidak hanya sebagai seorang guru namun juga sebagai sosok ayah kepada anak-anaknya yang patut diteladani dan dijadikan panutan. Dalam hal ini Yai Chamzawi melakukan interaksi fisik, yang artinya selalu menghadirkan dirinya ditengah-tengah para mahasantri di setiap acara, serta memberikan peluang interaksi yang bersifat edukatif - demokratis selama 24 jam. Kebanyakan dalam berinteraksi dengan santrinya Yai Chamzawi lebih banyak memberikan motivasi melalui mauidhoh hasanah kepada mereka untuk selalu semangat dalam mencari ilmu di Perguruan Tinggi. Selain itu Yai Chamzawi juga menggunakan pendekatan motivasi penteladanan (uswah), misalnya Yai Chamzawi memberikan contoh kepada mahasantrinya dengan senantiasa shalat lima waktu berjamaah secara istiqamah (continual). Sehingga dengan adanya interaksi yang akrab antara kiai dengan mahasantri, menunjukkan bahwa kiai sebagai pengasuh MSAA memberikan peluang untuk intensifikasi pendidikan.

Kedua, interaksi Yai Chamzawi dengan bawahannya yang dalam hal ini meliputi dosen, asatidz, pengurus serta staff lebih banyak dilakukan melalui interaksi pola pikir. Sebagai seorang pemimpin di MSAA, Yai Chamzawi tidak pernah mengabaikan suara yang keluar dari bawahannya, sehingga dalam proses pelaksanaan program di MSAA Yai Chamzawi selalu mengajak bawahannya untuk bertukar pikiran dan berdiskusi terlebih dahulu. Hal tersebut merupakan salah satu bangunan interaksi yang berkelanjutan dengan maksud agar mereka dapat merasa menjadi bagian dari pondok pesantren. Interaksi tersebut dilakukan setiap saat secara individu, karena Yai Chamzawi sendiri lebih suka diskusi secara empat mata, namun ada kalanya Yai Chamzawi berinteraksi dengan semua anggotanya yang dilakukan pada pertemuan rutin setiap akhir bulan untuk melakukan muhasabah dan juga pemberian motivasi.

Ketiga, selain melakukan interaksi dengan komunitas internal pondok pesantren, Yai Chamzawi juga melakukan interaksi dengan komunitas eksternal pondok pesantren yang dalam hal ini adalah 
Devi Pramitha - Kepemimpinan Kyai dalam Mengaktualisasikan Modernisasi Pendidikan Pesantren di Perguruan Tinggi (Studi Interaksionisme Simbolik Di Ma'had Sunan Ampel al-'Aly Uin Maliki Malang)

masyarakat. Interaksi ruh yang dilakukan oleh Yai Chamzawi kepada masyarakat melalui kegiatan-kegiatan spiritual seperti, acara keagamaan yang merupakan salah satu media Kyai untuk berinteraksi dengan masyarakat.

Sejalan dengan yang diungkapkan oleh Horikhoshi, bahwa kiai mempunyai peran kreatif dalam perubahan sosial, yaitu memperkenalkan unsur-unsur sistem luar dan menimbulkan perubahan dalam masyarakat. Perubahan sosial yang terjadi di pondok pesantren yang kemudian berdampak pada masyarakat secara positif disebabkan oleh peran aktor kiai. Proses perubahan ini bisa dicermati pada peran-peran pondok pesantren dalam membawa pesan agama yang dibingkai dengan sistem nilai yang ada di masyarakat, seperti sikap saling menolong, sikap kesopanan, semangat hidup dalam berusaha dan bekerja bahkan mengajak untuk mulai terbuka dengan hal-hal baru di masyarakat seperti teknologi dan globalisasi.

Adanya interaksi antara pimpinan dan bawahan merupakan salah satu bagian penting bagi setiap organisasi, termasuk organisasi pesantren yang ada di Perguruan Tinggi. Walaupun pimpinan MSAA adalah seorang Kyai, namun bukan berarti harus menutup diri dengan bawahannya, sebaliknya Kyai harus sering melakukan interaksi tidak hanya dengan komunitas internal Perguruan Tinggi saja, namun dengan komunitas eksternal Perguruan Tinggi juga perlu dilakukan. Hal itu senada dengan teori interaksi (interaction theory) yang pada prinsipnya sama dengan kontingensi (contingency theory) dari F. E. Fiedler dan expectancy-reinforcement theory dari Ralph M. Stogdill. Dimana teori interaksi ini berasumsi bahwa semakin sering terjadi interaksi dan partisipasi dalam kegiatan bersama, semakin meningkat pula perasaan saling menyenangi satu sama lain dan saling memperjelas pengertian atas norma kelompok.

Interaksi fisik yang dilakukan oleh Yai Chamzawi terhadap mahasantri akan memunculkan sikap tawaddu santri terhadap kyai dan memunculkan istilah ngalap barokah yang artinya santri akan menuruti apa saja yang dikatakan dan diperintahkan oleh Yai Chamzawi guna mengharap barakah ilmu yang dipelajarinya di pondok pesantren. Sedangkan interkasi pola pikir yang dilakukan oleh Yai Chamzawi terhadap anggota bawahannya, juga interaksi ruh yang dilakukannya kepada masyarakat akan memunculkan sikap ketaatan, kesetian dan kepatuhan (loyalitas) yang tinggi dari anggota bawahan maupun masyarakat terhadap Kyai dan MSAA. Hal itu senadan dengan gaya kepemimpinan tradisional yang dipaparkan di bab II bahwa Max Weber mengemukakan dalam kepemimpinan tradisional, kepatuhan 
diberikan kepada orang atau pemimpin yang menduduki kekuasaan tradisional yang terikat pula dalam suasana tersebut. Pengikut patuh pada pimpinan tidak didasarkan pada tatanan impersonal, tetapi menjadi loyalitas pribadi dalam ruang lingkup dengan membiasakan tunduk pada kewajiban.

Dari pembahasan di atas berkenaaan dengan terjadinya interaksi kiai dengan komunitas internal dan eksternal MSAA maka dirumuskan proposisi sebagai berikut:

Interaksi yang dilakukan oleh Yai Chamzawi dengan komunitas internal dan eksternal MSAA melalui pola interaksi dengan varian model; Interaksi fisik (al-mu'amalah al-jismiyah), interaksi pola pikir (al-mu'amalah al-fikriyah), dan interaksi ruh (al-mu'amalah al-rûhiyah) memunculkan sikap ketaatan, kesetian dan kepatuhan (loyalitas) yang tinggi, sehingga mengarah kepada gaya kepemimpinan tradisional

\section{Implikasi Positif Kepemimpinan Kyai dalam Mengaktualisasikan Modernisasi Pendidikan Pesantren di Ma'had Sunan Ampel Al-'Aly UIN Maulana Malik Ibrahim Malang}

Dampak dari kepemimpinan Drs. KH. Chamzawi, M.HI dalam mengaktualisasikan konsep modernisasi pendidikan pesantren di Perguruan Tinggo ini terlihat dari aspek sistem/ metode pengajarannya. Dari segi sistem/ metode pengajaran tidak lagi menggunakan sistem pengajaran yang konservatif seperti sorogan, bandongan, ataupun wetonan, sedangkan untuk metode pembelajaran yang digunakan juga dilakukan modifikasi, Yai Chamzawi tidak ingin metode pembelajaran yang digunakan hanya bersifat tekstual saja namun juga harus bersifat kontekstual. Artinya dosen/ asatidz tidak hanya cukup dengan ceramah saja dalam menyampaikan pelajaran akan tetapi juga harus dipraktekkan secara langsung atau memberi kesempatan kepada para mahasantri untuk berdiskusi seperti dalam kegiatan bahtsul masail.

Dari segi sarana dan prasarana yang ada di MSAA dapat dibilang cukup menonjol dalam menunjukkan citranya sebagai Ma'had Al-Jami'ah. Ciri-ciri penampilan bangunan fisik di MSAA ini, pada dasarnya sesuai dengan hasil penelitian Becker yang menunjukkan bahwa lembaga pendidikan yang memancarkan kecermelangan (beacon of brilliant) adalah lembaga pendidikan yang memiliki gedung dan perlengkapan belajar memadai bagi murid, dan bukan sebagai sekolah yang digerogoti penyakit (pot-holes of pestilence) yakni memiliki bangunan yang kotor, tidak terawat, lingkungan tidak sehat 
untuk belajar dan pertumbuhan anak, serta sekolah yang kekurangan staf dan peralatan (Becker, 1971: 267 - 304).

Implikasi positif dari kepemimpinan Yai Chamzawi adalah pengelolaan MSAA dengan menggunakan prinsip al-muhafadzatu 'alal qadimi shalih wal akhdu bil jadidil ashlah.

\section{KESIMPULAN}

Berdasarkan fokus penelitian, paparan data dan temuan penelitian serta analisis data maka hasil penelitian ini dapat disimpulkan sebagai berikut:

1. Perilaku Kepemimpinan Drs. KH. Chamzawi, M.HI di Ma'had Sunan Ampel Al-Aly dapat dikategorikan sebagai berikut: (a) Kharismatik; (b) Inspirator; (c) Motivator; dan (d) Demokratis. Perilaku kepemimpinan Yai Chamzawi tersebut mengarah kepada gaya kepemimpinan transformasional.

2. Pola Interaksi Kepemimpinan Drs. KH. Chamzawi, M.HI baik dengan mahasantri, dosen, maupun masyarakat di sekitar MSAA melalui interaksi aktif, meliputi: (a) Interaksi fisik (al-mu'amalah al-jismiyah); (b) Interaksi pola pikir (al-mu'amalah al-al-fikriyah); dan (c) Interaksi ruh (al-mu'amalah al-rûhiyah) yang memunculkan sikap ketaatan, kesetian dan kepatuhan (loyalitas) yang tinggi mengarah kepada gaya kepemimpinan tradisional.

3. Implikasi positif dari Kepemimpinan Drs. KH. Chamzawi, M.HI di MSAA terlihat pada aspek Sistem Pengajaran dengan menggunakan prinsip al-muhafadzatu 'alal qadimi shalih wal akhdu bil jadidil ashlah

Sehingga dari ketiga kesimpulan diatas dapat peneliti dapat menemukan gaya kepemimpinan Drs. KH. Chamzawi, M.HI di Ma’had Sunan Ampel Al-'Aly UIN Maliki Malang adalah Gaya Kepemimpinan Neo-Transformasionalisme. Gaya kepemimpinan NeoTransformasionalisme adalah gabungan dari gaya kepemimpinan transfomasionalisme dan gaya kepemimpinan tradisionalisme yang dilandasi dengan prinsip al-muhafadzatu 'alal qadimi shalih wal akhdu bil jadidil ashlah.

\section{DAFTAR PUSTAKA}

Abdalah, Ulil Abshar. 1999. Humanisasi Kitab Kuning: Refleksi dan Kritik atas Tradisi Intelektual Pesantren, dalam Marzuki Wahid, dkk (Edit.), Pesantren Masa Depan: Wacana Pemberdayaan dan 
Devi Pramitha - Kepemimpinan Kyai dalam Mengaktualisasikan Modernisasi Pendidikan Pesantren di Perguruan Tinggi (Studi Interaksionisme Simbolik Di Ma'had Sunan Ampel al-'Aly Uin Maliki Malang)

Transformasi Pesantren. Bandung: Pustaka Hidayah

Azra, Azyumardi. 1999. Pendidikan Islam: Tradisi dan Modernisasi Menuju Millenium Baru. Jakarta: Logos

Madjid, Nurcholis. 1997. Bilik-Bilik Pesantren: Sebuah Potret Perjalanan. Jakarta: Paramadina

Maunah, Binti. 2009. Tradisi Intelektual Santri. Yogyakarta: Teras

Sulaiman, In'am. 2000. Masa Depan Pesantren: Eksistensi Pesantren di Tengah Gelombang Modernisasi. Malang: Madani

Ulfatin, Nurul. 2013. Metode Penelitian Kualitatif di Bidang Pendidikan. Malang: Bayumedia Publishing

Umiarso \& Nur Zazin. 2011. Pesantren di Tengah Arus Mutu Pendidikan: Menjawab Problematika Kontemporer Manajemen Mutu Pesantre. Semarang: RaSAIL Media Group

Wahid, Abdurrahman. 1987. Principle of Pesantren Education, the Impact of Pesantren in Education and Community Development in Indonesia. Berlin; Technical University Berlin

West, Richard dan Lynn H. Turner. 2008. Pengantar Teori Komunikasi: Analisis dan Aplikasi. Buku 1 edisi ke-3. Terj: Maria Natalia Damayanti Maer. Jakarta: Salemba Humanika

Yukl, Gary. 2009. Kepemimpinan dalam Organisasi (Leadership in Organization), edisi kelima Bahasa Indonesia. Jakarta. 